\title{
Discussing Post-Colonization and Tourism in Jamaica
}

\author{
Gaunette Sinclair-Maragh ${ }^{1 *}$ and Douglas L Hoston ${ }^{2}$ \\ ${ }^{1}$ College of Business and Management, University of Technology, Jamaica \\ ${ }^{2}$ Department of Learning and Instruction, University of Buffalo, USA
}

Submission: November 11, 2017; Published: March 06, 2018

*Corresponding author: Gaunette Sinclair-Maragh School of Hospitality and Tourism Management, College of Business and Management, University of Technology, Jamaica, Email: gmaragh@utech.edu.jm

\begin{abstract}
This is a discussion on the relationship between post-colonization and tourism in Jamaica. The postcolonial theory is used to expand the epistemology of the relationship between post-colonization and tourism and provide plausible explanations concerning their association. This discussion paper also serves to advance the paradigms of cultural identity and the three presences by linking them to the concepts of nation culture and national identity, and how these phenomena help to stimulate the development of tourism in Jamaica. Additionally, the concept of the tourist gaze is incorporated in the analysis to show how post-colonization serves the tourists from both site and event attraction experiences. This ostensibly benefits Jamaica socially, culturally and economically. In summary, the discussion paper analyzes the impact of post-colonization on tourism in Jamaica and is intended to create a better understanding regarding the use of a destination's cultural and historic legacies for tourism. It will also contribute significantly to the areas of tourism planning and development, destination marketing, anthropology, sociology, psychology and cultural studies.
\end{abstract}

keywords: Post-Colonization; Tourism; Cultural identity; Shared culture; Sense of difference; Three presences

\section{Introduction}

Tourism is not a new phenomenon to Jamaica as it became an economic activity over 200 years ago [1]. Xaymaca, the land of wood and water as exclaimed by Christopher Columbus, has become a renowned destination since the $19^{\text {th }}$ century when Captain Lorenzo Baker brought the first set of tourists from the United States of America on his banana boat [2]. Although the wood and water have been Jamaica's focal tourism offering for scenic view and water activities, there are other features of this Caribbean island destination that contribute to the experience of the tourists. These include the Jamaican people, cuisine, places of interest and sporting activities to name a few. Interestingly, these can be described as legacies of colonization and manifestations of the plantation system and thus, features of post-colonization. The concept of post-colonization is described as anything that happens after the colonization era [3].

Despite the many writings on Jamaica's history, heritage and culture, the gap in the literature shows the need to conduct an in-depth analysis of the relationship between post-colonization and tourism in Jamaica. The understanding of the relationship between post-colonization and tourism is not widespread. Likewise, the use of its cultural and historic legacies for tourism may not be fully accepted. This is because the plantation system is viewed as an institutional arrangement where forced labor is used for the production and marketing of crops. The belief is that this historical epoch is currently impacting the social structure of the Jamaican society [4].

A study of this nature specifically focusing on Jamaica is however, fundamental as this destination highly depends on the tourism economy [5] as well as it epitomizes the transition from colonization to decolonization and by extension postcolonization. Consequently, the remnants of Jamaica's history have become extremely useful as a part of its tourism product. The purpose of this paper, therefore, is to critically discuss the notion of post-colonization and its relationship with tourism in Jamaica. It particularly examines the works of Stuart Hall relating to cultural identity and Aime' Cesaire' regarding the three presences, namely, African, European and American. The discourse of cultural identity is explained within two frameworks; the first one refers to shared culture which is based on collectivism and describes the 'one true self' and the second is associated with the "sense of difference" which pertains to the transformation and reshaping of culture. The three presences characterize the nature of post-colonization in terms of the cultural background of the Jamaican people, the socio-political structure which governs the people and the expectations of the visitors.

This discussion paper advances the paradigms of cultural identity and the three presences by linking them to the concept 
of nation culture and how this phenomenon helps to stimulate the development of tourism in Jamaica. The post-colonial theory establishes the framework of this discussion because it explains the cultural aspects of post-colonies and analyzes the cultural legacy of colonization. It will provide plausible explanations for the association between post-colonization and tourism since many colonies are now tourist destinations [6] where their culture and heritage are being used for tourism [7].

\section{Discussion}

\section{Post-colonization and tourism in Jamaica}

Jamaica has a very rich cultural background that is linked to its colonial history. Prior to the Europeans (Spanish and English) in the $15^{\text {th }}$ century, the island was inhabited by the Amerindians. Jamaica was subsequently colonized by the Europeans who institutionalized forced labor supported by the African slave trade. After the abolition of slavery in 1834, the Chinese and Indians were taken to the island as alternate labor force for the plantations.

The rich cultural and heritage platform on which Jamaica stands is due to the "presences" of the ethnic groups who populated Jamaica and which have established the identity of the Jamaican people as well.

Within this context, it is important to outline the paradigms of cultural identity and the three presences as they relate to the concepts of nation culture and national identity and how these phenomena help to stimulate the development of tourism in Jamaica. The following section will also explain how the tourist gaze as proposed by Urry J [8] is stimulating economic activity for Jamaica through its post-colonization features.

\section{Cultural identity}

The traditions and practices of the various ethnic groups who populated Jamaica have culminated to form the Jamaican culture which has been passed on from one generation to another. Based on this historical amalgamation of culture, the two frameworks of cultural identity proposed by Stuart Hall, a Jamaican-born culturalist and sociologist seem applicable in explaining the phenomenon of being a Jamaican. These are the principles of shared culture and the sense of difference [9].

Because the Jamaican people can be described by the collective characteristics that depict 'one true self' with a 'oneness' of what they do and how they do it, this phenomenon can be explicitly explained as shared culture. Despite having a shared culture, each ethnic group, namely the dominant African-Jamaican (Black), Indian, Chinese, or Jamaican-White, is identifiable by their distinct culture and this speaks to the sense of difference. The practices of the shared culture yet the distinctive differences among the ethnic groups have now become a major post-colonization hallmark for Jamaica and are been used or incorporated into the tourism offerings by way of its music, dance, food, local language and other elements of attraction.
The shared culture has created a national identity for the Jamaican people. This national identity which stems from colonization is actually benefitting the country as the remnants of slavery are now legacies for the tourism industry. For example: the Jamaican cuisine including the use of the jerk cooking method and jerk sauces is a major aspect of the tourism product. This practice was developed by the African, now named Maroons who ran away to the mountains. They used this method of cooking to sustain themselves, having only natural resources from the vegetation and animals in the mountains. Another example is that the local dance movements are an amalgamation of the European ball room and African dance forms.

Despite the importance of having a distinct national identity where it creates and establishes a stable nation and country, it is believed that it "can limit the social, cultural, and economic progress of a decolonized people" [10]. The national identity of Jamaica, however, appears to be beneficial to tourism as the purpose of visit to the destination for the majority of tourists/ visitors fall in the category of leisure, pleasure and holiday (73.3\%) when compared to other reasons such as business or visiting friends and family [11]. This category of travel includes visits to heritage sites, local entertainment and cuisine among other culture and heritage offerings.

\section{The three presences}

The three presences posited by Aime' Cesaire', a politician and author from Martinique, regarding the African, European and American influences is also important for Jamaica's tourism. As explained below, the presences of the Europeans, Africans and Americans in Jamaica have significantly influenced the political, social, cultural and economic structure of the country and consequently tourism development.

The Europeans: The Europeans characterized the nature of post-colonization in terms of the socio-political structure which governs the country. The Spanish were enterprising with the slave trade by bringing Africans to Jamaica. Then the British arrived and they continued with colonization where African slaves were used as forced laborers for the production of sugar cane and its derivatives such as sugar and molasses, as well as tobacco and other agricultural provisions.

With the colonized system, the Europeans established models of the socio-economic and political governance structure from Europe. The British succeeded the Spanish in ruling Jamaica and hence, their systems and institutions are more predominant in Jamaica. The current institutions in Jamaica remain models of the British system; hence, they influence the socio-political environment of the nation. The parliamentary, judiciary and education institutions are examples of the British model. The parliamentary institution regulates the operations of the tourism industry through the establishment of government ministry and agencies for planning and marketing, as well as instituting laws and policies. The judiciary framework regulates the laws and the education institutions train individuals for the tourism industry. 
Consequently, the British influences the cultural practices of Jamaicans. This according to Antonio Gramsci, an Italian politician, suggests cultural leadership which denotes the dominance of certain cultural forms. Cultural leadership is associated with the concept of hegemony which is the leadership or dominance by a country or social group over another, thus, the term cultural hegemony. It is believed that cultural hegemony can manipulate the culture of the society through the imposition of beliefs, explanations, perceptions, values and mores [12]. Said EW [13] emphasize Gramsci's theory of cultural hegemony within the context that hegemony is important in understanding the cultural life of the industrial West society. It is the belief that the European culture is hegemonic and this makes the European identity superior when compared to Non-European people and cultures, both in and outside of Europe.

The Europeans have also left their mark on the physical surroundings as there are now places of interests that are being used as attractions for tourists. For example, the many great houses, once known as plantation houses which accommodated the plantation/slave owners. These include the Seville, Bellefield, Halse Hall and Greenwood Great Houses. Some of the vernacular architecture of the Europeans still remain as in the case of Spanish Town, the first capital of Jamaica. The Catholic Churches established by the Spanish and the Anglican churches by the British show the difference in architectural design and the distinguishing red and brown bricks respectively. In relation to sporting activities, the game of cricket was brought here by the English. It was further incorporated into the Jamaican culture by the Indians whose country was similarly colonized by the British. In 2008, the Cricket World Cup was held in the Caribbean. Jamaica was one of its main hosts and the event attracted many visitors to the island [14].

The Africans: The presence of the Africans is one of the most distinguishing features of post-colonization in Jamaica. Today, the majority of the Jamaican population is of African heritage [15]. This majority black population has a resounding mark on Jamaica's culture which is incorporated into the tourism offerings. For example, the amalgamation of their particular food, flavor and cooking practices have tremendously contributed to the uniqueness of the Jamaican cuisine. A typical example is ackee and saltfish with roast breadfruit; the ackee was brought from West Africa and the breadfruit brought by Captain Blight from Tahiti. Interestingly, this dish includes salted cod fish which was brought by the Europeans and used as ration for the slaves. The palatable rice and peas is a one pot meal cooked by the slaves to "stretch" the meal for the family. Gizzada, grater cakes and drops were local confectionaries made by the African slaves to pattern the European pies and confectionaries. Cornmeal and potato puddings also patterned the European cakes and puddings. The process of jerk and the use of the specific marinates were conceptualized by the Maroons when they lived in the hills and had to find creative means of sustaining their diet. They hunted wild pigs, seasoned them with natural herbs and used pimento sticks over pits to cook the meat, resulting in today's delectable delights of jerk pork, chicken and even fish; and bottled seasoning sold to tourists.

The Jamaican spoken language, Patois, is very distinctive and distinguishing. This highly admirable language comprises a mixture of West and Central African; and European languages, predominantly English and French. Its emergence stemmed from the creativity of the African slaves in developing a language to communicate among them as they were from different parts of Africa. Interestingly, no matter the ethnic background of a Jamaican, Patois is known, understood and spoken and therefore, symbolizes Jamaica. Visitors to Jamaica yearn to speak this local language.

The Americans: The presence of the American is also an important element of tourism in Jamaica as they were among the first tourists to visit this destination [1]. According to the Jamaica Tourist Board (2016), of the 2,181,684 stopover visitors to the destination in 2015, majority of them (64.4\%) are from the United States of America (USA) when compared to other source markets as indicated in Table 1.

Table 1: Tourism Source Markets for Jamaica.

\begin{tabular}{|c|c|c|}
\hline Source Markets & Stopover Arrivals & \% Share \\
\hline USA & $1,406,058$ & 64.4 \\
\hline Canada & 372,137 & 17.1 \\
\hline Europe & 294,709 & 13.5 \\
\hline Caribbean & 65,592 & 3.0 \\
\hline Latin America & 27,726 & 1.3 \\
\hline Other Countries & 15,462 & 0.7 \\
\hline
\end{tabular}

Table 2: Distribution of Expenditure of Stopover Visitors in 2015.

\begin{tabular}{|c|c|}
\hline Tourism Offerings & \% Expenditure \\
\hline $\begin{array}{c}\text { Accommodation including Food } \\
\text { \& Beverage }\end{array}$ & 54.2 \\
\hline Food \& Beverage & 5.1 \\
\hline Entertainment & 13.4 \\
\hline Transportation & 6.2 \\
\hline Shopping & 5.4 \\
\hline Miscellaneous & 15.7 \\
\hline
\end{tabular}

This has been the trend for many years where almost twothirds of the market source for tourism in Jamaica is from the USA. This suggests that this market segment has been contributing to the economy in a significant way through their spending on the tourism offerings. In 2016, stopover visitors to Jamaican spent an estimated total of US $\$ 2.459$ million [11]. Excluding the amount spent on food and beverage included in the expenditure for accommodation Table 2 shows that 24 percent collectively is spent on food and beverage, entertainment and shopping. These are likely to include elements of the Jamaican culture. 


\section{Tourist gaze}

[8] purports that the gaze is a central element of the tourist's experience. The visual aspect of a destination is a very important feature of a tourist gaze. These are pull factors for tourists that will add pleasure to their encounters [16] and further motivate them to revisit the destination. Studies show that the "new tourist" desires more than the sun, sand and sea offerings. They seek adventure; they want to explore; they are desirous of being educated and informed; and they want to be involved and participate in cultural and heritage activities [17]. The postcolonization tourism offerings in Jamaica provide the desired gaze and experience for the tourists.

Through visits to culture and heritage sites such as the Maroon villages, GREAT HOUSES, historical towns to include Falmouth and Spanish Town; events to include Reggae Sumfest and Fun in the Son (annual gospel event); street food events and sites, and the natural landscape such as Fern Gully, Holland Bamboo and Black River, visitors are able to gaze on these features for fun and ecstasy.

According to [18] these cultural representations actually define tourism. Furthermore, their pictorial depictions and images are used as memorabilia and as Pine II and Gilmore (1999) purports; they positively influence the visitors' experience.

Sinclair-Maragh G [20] adds that visitors tend to take souvenirs back home with them and this entices them to recall their visit and share their experiences with others. Visual images are likewise important in marketing a destination [19]. However, in examining the visual images used in marketing Jamaica's tourism, Walters $\mathrm{NH}$ [16] find that post-colonial images representing the heritage and material culture of Jamaica was not widely used when compared to both elements of paradise/ recreation images and nature/landscape images. Nonetheless, this category is one of the dominant thematic groups identified in the marketing thrust. The images in this category represent cultural events, local cuisine and art as well as historical sites. They have the propensity to create competitive advantage for the destination as persons will be motivated to travel to the destination when these are seen.

\section{Conclusion}

The purpose of this study is to provide a stimulating discussion on the relationship between post-colonization and tourism in Jamaica, using postcolonial theory to expand the epistemology of the relationship and provide plausible explanations concerning their association. The discussion surrounding the relationship between post-colonization and tourism is imperative because the economy of Jamaica highly depends on this industry for sustainability. The analysis shows that Jamaica's uniqueness is underpinned by the shared culture from ethnic and racial diversity in its population as well as from the sense of difference within each of these groups. Additionally, the remnants of Jamaica's history based on its colonial jurisdictions have become extremely significant to its tourism product as the new type of tourist is seeking a fulfilling experience through adventure, exploration, education and engagement with the local culture and heritage assets. These post-colonial elements are in fact being used to provide such experiences.

The postcolonial theory has provided explanations to the relationship between post-colonialism and tourism as it explains the cultural legacies of colonialism left by the Europeans. These include the introduction of immigrants (Indian and Chinese) to the socio-economic framework, the political structure, education system among other elements which dictate and guide the management of tourism as an industry in Jamaica. It also explains the use of post-colonization elements for the tourist gaze in that the culture and heritage tourism offerings are from that era and they now provide attraction, entertainment and education for visitors.

This discourse regarding post-colonization and tourism may be controversial but obviously the aforementioned features of the Jamaican society which are the legacies of colonization are actually being used for tourism. This can be the catalyst for the future growth and development of tourism in Jamaica through product diversification, leading to the destination having a competitive advantage within the Caribbean. This is especially important since countries in this region also rely heavily on tourism. This form of tourism can complement the mass tourism feature of the sun, sand and sea as well as serve as an alternative form of tourism for tourists to be engaged and participate in these offerings.

\section{References}

1. Taylor FF (1993) To hell with paradise: A history of the Jamaican Tourist Industry. University of Pittsburgh Press, London, UK.

2. Gauron M (2002) Jamaica Collector's Edition. Deeks Design Kingston, Canada.

3. Ashcroft B, Griffiths G, Tiffin H (1998) Key concepts in post-colonial studies. Psychology Press.

4. Persaud RB (2001) Counter-hegemony and foreign policy: The dialectics of marginalized and global forces in Jamaica. SUNY Press, USA.

5. Sinclair-Maragh G, Gursoy D (2015) Imperialism and tourism: The case of developing island countries. Annals of Tourism Research 50: 143158.

6. Craik J (1994) Peripheral pleasures: The peculiarities of post-colonial tourism Culture and Policy 6(1): 21-31.

7. Smith VL (1996) Indigenous tourism: The four Hs. In: R Butler \& T Hinch (Eds.), Tourism and indigenous peoples. International Thomson Business Press, London, UK, pp. 283-307.

8. Urry J (1990) The tourist gaze: Leisure and travel in contemporary societies. Sage, London.

9. Hall S (1994) Cultural identity and diaspora. In: Williams Patrick \& Chrisman Laura (Eds.), Colonial discourse and post-colonial theory a reader. New York Columbia University Press. USA, pp. 392-403.

10. Ayubi N (2001) Overstating the Arab State. In: Tauris IB (Eds.) Bodmin, UK Co Ltd. UK, pp. 148. 
11. Jamaica Tourist Board (2016) Annual Travel Statistics.

12. Bullock A, Trombley S (1999) The New Fontana Dictionary of Modern Thought ( $3^{\text {rd }}$ edn), pp. 387-388.

13. Said EW (1978) Orientalism. Pantheon Books, New York. USA.

14. Sinclair-Maragh G (2010) A critical socio-economic assessment of the ICC World Cup Cricket on the hosting Caribbean territories. In: LeslieAnn Jordan, et al. (Eds.), Sports Event Management: The Caribbean Experience. Ashgate Publishers, Great Britain, UK.

15. Sinclair-Maragh G (2016) Demographic analysis of residents' support for tourism development in Jamaica. Journal of Destination Marketing \& Management

16. Walters NH, Cassel SH (2016) Still a White Paradise? Photographic Representations of Jamaica as a Tourism Destination. Tourism Culture \& Communication 16(1-2): 59-73.

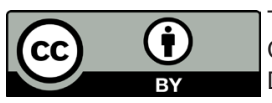

This work is licensed under Creative Commons Attribution 4.0 Licens

DOI: 10.19080/GJAA.2018.02.555596
17. Sinclair-Maragh (2014) Resort-based or resource-based tourism? A case study of Jamaica. Emerald Emerging Markets Case Studies 4(2): 1-19.

18. Wolcott HF (1995) Making a Study" More Ethnographic". In: Teoksessa J van Maanen (Eds.), Representation in Ethnography, pp. 79-110.

19. Jenkins $O$ (2003) Photography and travel brochures: The circle of representation. Tourism Geographies 5(3): 305-328.

20. Sinclair-Maragh G (2016) Assessing Tourism Experiences: The Case of Heritage Attractions. The Handbook of Managing and Marketing Tourism Experiences. Emerald Group Publishing Limited, pp. 487-506.

\section{Your next submission with Juniper Publishers will reach you the below assets}

- Quality Editorial service

- Swift Peer Review

- Reprints availability

- E-prints Service

- Manuscript Podcast for convenient understanding

- Global attainment for your research

- Manuscript accessibility in different formats

( Pdf, E-pub, Full Text, Audio)

- Unceasing customer service

Track the below URL for one-step submission

https://juniperpublishers.com/online-submission.php 